\title{
REACHING ASYNCHRONOUS LEARNERS WITHIN THE SILVER TSUNAMI
}

\author{
Linda F. Ettinger \\ Applied Information Management Master’s Degree Program \\ University of Oregon
}

\begin{abstract}
This paper provides a profile of the population niche known as baby boomers, seniors and retired, collectively called the silver tsunami, relative to the potential for growth of the number of asynchronous online learners. General contextual information concerning population statistics, computer use and access trends, prefaces a listing of learning in retirement programs associated with institutions of higher education in the United States.
\end{abstract}

\section{KEYWORDS}

Baby Boomers, Seniors, Retirees, Lifelong Learning

\section{POPULATION TERMS \& DEMOGRAPHICS}

What terms are used to describe this niche group?

What are the population numbers and projections?

\section{A. Terms}

The terms and range in years used to describe the age demographic of this group vary in the literature, as defined by four tiers: adults (ages 18 and over); middle-aged (ages 30-49); baby boomers and seniors (ages 50-64); and elderly and retired (ages 65+). Distinguishing among these age groups provides a way to set the parameters for meaningful discussion. It is important to note that we should not be focusing on "adults" or "elders" when examining this population niche for ALN growth potential. Instead, we should focus on "baby boomers", "seniors" and "retired"-collectively defined as the silver tsunami. Seattle architect William Kreager coined this term to describe the tidal wave of baby boomers about to impact the housing market.

\section{B. Projections}

Knable [1] reports that more than 76.1 million Americans were born in between 1946-1964. These Baby Boomers are now between the ages of 41 and 59. According to the Administration on Aging, by 2010, there will be 35 million people in the US between the ages of 55-64 [2]. This equates to $12 \%$ of the total population. In addition, there will be 21 million people between the ages of $65-74$, or $7 \%$ of the population. By 2050, people over 65 will outnumber children 14 or younger. The table below (see Table 1) shows that according to the Pew Internet \& American Life Project [3], 63\% of 50-64 year olds currently go online in some way, along with $26 \%$ of those over 65 . The experts are startled that educational institutions have changed so little, despite widespread expectations a decade ago that school would be quick to embrace change (Pew Internet \& American Life Project, 2005). 


\begin{tabular}{|c|c|}
\hline Group/Age & Percent Who Go Online \\
\hline Total Adults & $66 \%$ \\
\hline Women & $65 \%$ \\
\hline Men & $66 \%$ \\
\hline Age & $81 \%$ \\
\hline $18-29$ & $78 \%$ \\
\hline $30-49$ (middle aged) & $\mathbf{6 3 \%}$ \\
\hline $\mathbf{5 0 - 6 4}$ (Seniors/Boomers/Silver Tsunami) & $26 \%$ (about 10 million Americans) \\
\hline 65+ (retired/elderly) & \\
\hline
\end{tabular}

Table 1: (Pew Internet \& American Life Project, January 2005 Tracking Survey)

\section{COMPUTER USE, INTERNET ACCESS \& MOTIVATION}

What are the computer usage trends?

What are the Internet access issues?

There is a burgeoning group of Americans who are slightly younger than typical retirees (62-65) and who are vastly more attached to the online world. This "Silver Tsunami" identified in the Pew Internet Project 2001 "Wired Seniors" report has gained momentum [4]. Eight in ten baby boomers say they will continue to work at least part time when retired.

A report of Internet access in February 2004 revealed that within the group of Americans aged 50-58, $62 \%$ had Internet access, and within the group of Americans aged 59-68, 46\% had Internet access [4].

As Internet users in their 50s get older and retire, they are unlikely to give up their wired ways and therefore will transform the wired senior stereotype [5].

Seniors are often placed in the "late adopter" category-people who use the Internet to increase productivity or to become more connected with friends and family. Since 1995 (or during the past ten years) people aged 50-64 and 65+ have steadily increased Internet use from $0 \%$ to $26 \%$ and $10 \%$ to $63 \%$, respectively [6].

In the article Why Are Baby Boomers Returning to College? Knable attempted to determine why baby boomers are returning at record-breaking rates. Boomers' motivation for returning to college fell into two main categories: Employment (to enhance opportunities, fight obsolescence, increase job security, achieve promotion, second career); and Personal (hobby, health, expand horizons). In addition, eight in ten baby boomers say they will continue to work at least part time when retired.

An important factor in relation to ALN is the rapid switch from dial-up access to high-speed broadband connections. This allows people to spend more time online, connecting to bigger information pipelines. Users report greater ease of use and satisfaction with the Internet [6]. To insure the highest level of access, both universal accessibility and universal usability must be addressed. Solutions that are applicable to many people, make implementation broadly useful and cost-effective [7]. 


\section{LIFELONG LEARNING PROGRAMS ASSOCIATED WITH INSTITUTIONS OF HIGHER ED}

What organizations serving this population are also connected to higher education? What initial strategy best supports productive asynchronous learning development?

There are a number of organizations in the US, tied directly to institutions of higher education, that support the lifelong continuing education interests of the silver tsunami (see list below). These include such groups as the Association of Continuing Higher Education (ACHE), the Association of Learning in Retirement Organizations of the West (ALIROW), the Bernard Osher Foundation, and Elderhostel. The characteristics of these types of programs in general include: (1) voluntary participation; (2) non-credit programs; and (3) a high degree of self-direction and organizational control.

The core of the problem of promoting growth in online learning in any higher education population is determining motivation - how do you get people started in online learning? Interest in participation in face-to-face lifelong learning groups appears to fall into three general categories, including the opportunity to engage with others, the challenge of learning, and the need to acquire specific information [8]. One strategy to add new asynchronous online learners among the silver tsunami population is to introduce the addition of an online community component within existing lifelong learning programs. Initially, the online community component could be designed as an addition to some part of already existing curriculum, such as an online discussion group attached to an ongoing face-to-face lecture series. This blended approach offers the opportunity for immediate application, providing an extended intellectual experience to current face-to-face participants. In addition, this approach provides an opportunity for new participants who cannot attend face-to-face activities for a whole host of reasons, including geography, health, time and weather. A list of potential lifelong learning organizations connected to higher education institutions in the United States follows, along with a secondary list of organizations that serve the population group, but are not connected to higher education.

\section{LIFELONG LEARNING ORGANIZATIONS CONNECTED TO HIGHER EDUCATION IN THE US}

\section{The Association of Continuing Higher Education (ACHE)}

http://acheinc.org/

Originally founded in 1939 as the Association of University Evening Colleges, ACHE's mission centered around professional development, colleagueship and personal service for administrators and faculty in evening colleges. Today ACHE is still committed to serve the professional development and growth of its members through evening programs, expanded continuing education, the growing number of adult students, the expanding changes in technology and training and retraining needs to meets the demands of economic development.

\section{Association of Learning in Retirement Organizations of the West (ALIROW) \\ http://www.alirow.org}

An active association of independent Learning in Retirement (LIR) associations whose member directed activities are generally located on campuses of sponsoring universities and colleges of the western US. Formally organized in 1984, ALIROW is the first umbrella organization to support university level, selfdirected learning institutes for the retirement age learners. ALIROW supports the educational objectives of all national associations related to learning in retirement. 


\section{Bernard Osher Foundation-Lifelong Learning Institute}

San Francisco, CA 94133

http://www.cel.sfsu.edu/olli/about.cfm

The Bernard Osher Foundation in San Francisco funds programs at universities nationwide aimed at aging baby boomers and envisioned as a new brain trust. Currently there are 73 Osher Lifelong Learning Institutes, comprising the membership of the Osher Lifelong Learning Institute National Resource Center. Each program is individual and independent in relation to approach and curriculum.

\section{The Elderhostel Institute Network (EIN)}

\section{http://www.elderhostel.org/ein/intro.asp}

The Elderhostel Institute Network is a voluntary association of Lifelong Learning Institutes (LLIs), funded by Elderhostel, Inc., a not-for-profit organization dedicated to providing educational opportunities for older adults. EIN exists to promote communication and provide resources to existing LLIs and to encourage the development of new LLIs. EIN does not prescribe fees or approve curriculum; those decisions are made independently by each LLI.

\section{University Continuing Education Association (UCEA)}

http://ucea.edu/

Founded in 1915 this Association assists institutions of higher learning and affiliated nonprofit organizations to increase access through a wide array of educational programs and services, as well as supporting policies that advance workforce and professional development. UCEA is committed to making higher education available to everyone.

\section{ORGANIZATIONS SERVING THE SILVER TSUNAMI, INDEPENDENT OF HIGHER EDUCATION}

The following organizations, while not directly connected to higher education, may provide useful marketing connections to the silver tsunami population.

\section{American Association of Retired Persons (AARP)}

http://www.aarp.org/

AARP is a nonprofit membership organization of persons over 50 and older designed to serve members needs and interests. AARP is active in all 50 United States, the District of Columbia, Puerto Rico, and the US Virgin Islands.

\section{NRTA: Retired Educators Associations (REAs) \\ http://www.aarp.org/about aarp/nrta/ed associations}

NRTA: AARP's Educator Community includes an affiliation with a network of Retired Education Associations (REAs) that represent and support retired educators across the country. The state REAs are independently incorporated, non-profit associations that advocate for the well being of retired educators on the state level.

\section{National Education Association-Retired}

http://www.nea.org/retired/about/index.html

NEA-Retired exists to meet the needs of retired education employees. This organization works with 
active NEA members to: Protect and improve retirement pension, and health benefits-including state pensions, Social Security and Medicare; Improve public education through mentoring, literacy, and intergenerational programs and activities; and achieve legislative and political action goals for education and education employees.

\section{Online Learning International (OLLI)}

http://www.olliolli.com/about/index.html

OLLI is a consulting and web based training company, based in Concord, Massachusetts. OLLI's programs and services are based on a sophisticated model for learning and decision support, developed by OLLI and its parent organization, the Concord Consortium. OLLI does receive major funding from the US Department of Education and the National Science Foundation.

\section{ABOUT THE AUTHOR}

Linda Ettinger is the Senior Academic Director for the Applied Information Management Master's Degree Program at the University of Oregon.

\section{REFERENCES}

1. Knabel, T. Why are baby boomers returning to college? 2005. Retrieved May 23, 2005 from http://adulted.about.com/cs/studiestats1/a/boomers_p.htm.

2. Administration on Aging. Statistics: aging into the $21^{\text {st }}$ century, 2004. Retrieved May 12, 2005 from http://www.aoa.gov/prof/Statistics/future_growth/aging21/table1.asp.

3. Pew Internet \& American Life project. January 2005 tracking survey, 2005.Retrieved April 27, 2005 from http://207.21.232.103/trends/User_Demo_03.07.05.htm.

4. Fox, Susannah. Wired seniors: a fervent few, inspired by family ties. Pew Internet \& American Life Project, 2001. Retrieved April 27, 2005 from http://www.pewinternet.org/report display.asp?r=40.

5. Fox, Susannah. Older Americans and the Internet. Pew Internet \& American Life Project, 2004. Retrieved April 27, 2005 from http://www.pewinternet.org/PPF/r/117/report_display.asp.

6. Rainie, Lee. Internet: The mainstreaming of online life, trends 2005. Pew Internet \& American Life Project, 2005. Retrieved June 10, 2005 from http://www.pewinternet.org/pdfs/Internet_Status_2005 .pdf.

7. Browne, H. Accessibility and usability of information technology by the elderly, 2000. Retrieved May 12, 2005 from University of Maryland, Department of Computer Science web site: http://www.otal.umd.edu/UUGuide/hbrowne.

8. Lamb, R. and E. M. Brady. Participation in Lifelong Learning Institutes: What turns members on? 2005. Retrieved May 23, 2005 from the University of Southern Maine, Osher Lifelong Learning Institute, National Resource Center web site: http://www.usm.maine.edu/olli/national/research.jsp. 